\title{
Dittrichia viscosa: Native-Non Native Invader
}

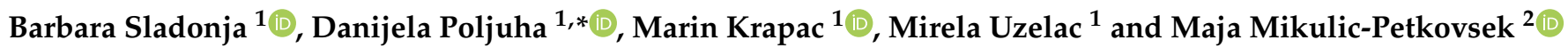 \\ 1 Institute of Agriculture and Tourism, Karla Huguesa 8, 52440 Poreč, Croatia; barbara@iptpo.hr (B.S.); \\ marin@iptpo.hr (M.K.); mirela@iptpo.hr (M.U.) \\ 2 Department of Agronomy, Biotechnical Faculty, University of Ljubljana, Jamnikarjeva 101, \\ SI-1000 Ljubljana, Slovenia; maja.mikulic-petkovsek@bf.uni-lj.si \\ * Correspondence: danijela@iptpo.hr; Tel.: +385-52-408-336
}

Citation: Sladonja, B.; Poljuha, D.; Krapac, M.; Uzelac, M.; Mikulic-Petkovsek, M. Dittrichia viscosa: Native-Non Native Invader. Diversity 2021, 13, 380. https:// doi.org $/ 10.3390 / \mathrm{d} 13080380$

Academic Editor: Michael Wink

Received: 14 July 2021

Accepted: 11 August 2021

Published: 15 August 2021

Publisher's Note: MDPI stays neutral with regard to jurisdictional claims in published maps and institutional affiliations.

Copyright: (c) 2021 by the authors. Licensee MDPI, Basel, Switzerland. This article is an open access article distributed under the terms and conditions of the Creative Commons Attribution (CC BY) license (https:// creativecommons.org/licenses/by/ $4.0 /)$.

\begin{abstract}
Dittrichia viscosa (L.) Greuter is a shrub native to the Mediterranean, however, declared as a very invasive species in Australia and North America. Environmental (climatic) and socio-economic (land abandonment) changes can trigger different adaptive mechanisms and cause changes in species behavior, influencing invasion dynamics. Motivated by the recently noticed change of $D$. viscosa behavior in its native Mediterranean habitat, we discuss the invasion properties, its behavior in the native habitat and new areas, and its management options. We review the species' adverse effects and its positive ecosystem services in the Millennium Ecosystem Assessment framework. In this review, we provide information on the phytochemical properties of $D$. viscosa and highlight its potential use in ecological agriculture, phytopharmacy, and medicine. The presented data is useful for developing effective management of this contentious species, with emphasis on mitigating environmental and economic damages, especially in agriculture. The final aim is to achieve a balanced ecosystem, providing a high level of possible services (provisioning, regulating, cultural and supporting).
\end{abstract}

Keywords: contentious invasive species; invasive properties; ecosystem services; phytochemical properties; weed

\section{Introduction}

Dittrichia viscosa (L.) Greuter, Stinkwort or False Yellowhead, is a perennial ruderal plant belonging to the Compositae family, native to the Mediterranean and Western Asia [1-3]. It is declared and listed on the Alert List of Environmental Weeds in Australia and North America [1]. It is abundant in anthropically altered areas [4]. In the Mediterranean, $D$. viscosa belongs to the vegetation of abandoned Mediterranean cultures, class of INULETEA VISCOSAE Trinajstić (1965) 1978; characteristic of the association Helichryso italici-Dittrichietum viscosae Trinajstić ex Di Pietro, Germani \& Fortini 2017 [5], a pasture of immortelle and false yellowhead [3,6]. Owing to its high seed production and spreading, good adaptability, and resistance to adverse conditions, it is considered an important environmental weed $[1,6]$. Recently an unusual spread of $D$. viscosa was recorded in coastal Croatia (personal records), causing functional and economic problems (Figure 1). Although there are no published quantitative data showing the spread of $D$. viscosa in Croatia, according to GBIF database (which included six different datasets) [7] from 2009 to 2020 number of observations have increased supporting our observations (Figure 2).

In neighboring Slovenia, it is considered indigenous and widespread [8]. Habitat changes in the Mediterranean basin, as well as in Croatia, are commonly linked to environmental and socio-economic alterations, land abandonment, and loss of traditional agricultural areas [9]. Climate change is one of the most significant environmental threats to biodiversity and has a number of potential effects on weeds in both agricultural and native vegetation landscapes $[10,11]$. It is known that climate variations can influence the spreading of invasive plant species [12-14]. Hence, established non-native species could become invasive if climate change increases their competitive ability or spreading rate [15]. 


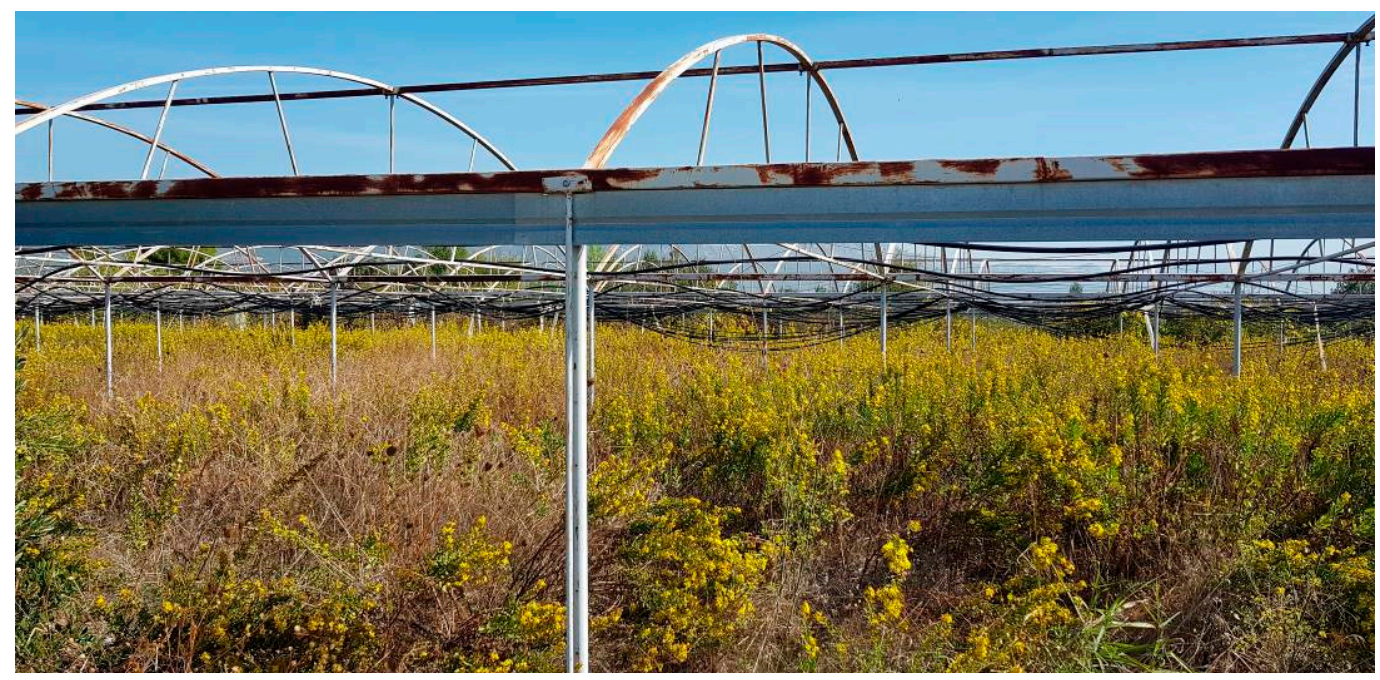

Figure 1. High abundance of Dittrichia viscosa on abandoned agriculture land in coastal Croatia.

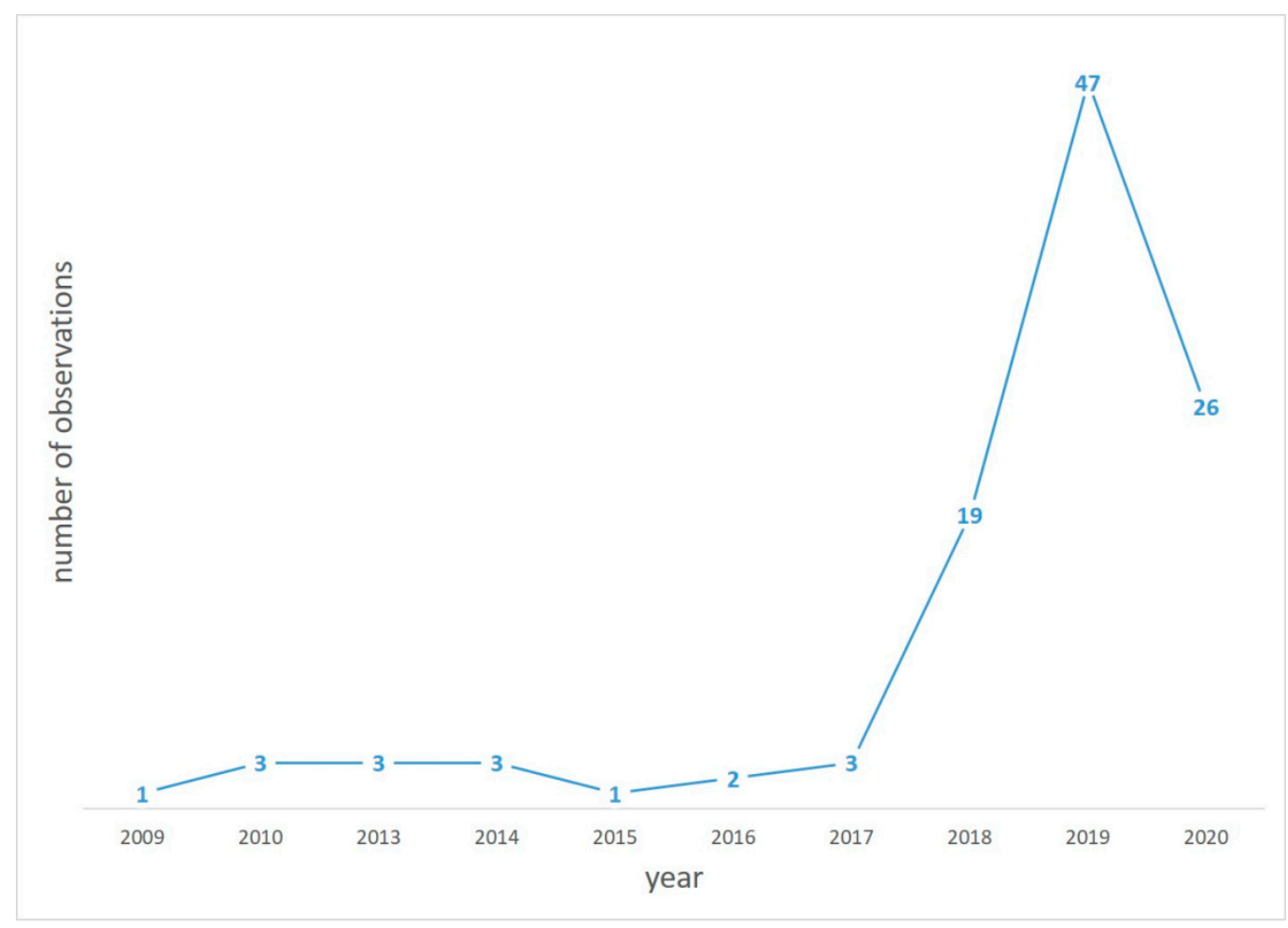

Figure 2. Number of observations of D. viscosa in the Republic of Croatia from 2009 to 2020.

However, to date, the characteristics that make species a successful invader or the ecosystem features that predispose it to invasion are still poorly understood [16,17]. Moreover, it is unclear which species or community attributes enhance invader success or explain spread dynamics [18]. Nevertheless, it has been shown that invasion success is dependent on unique interactions between the invader and the environment [19-22]. There are many hypotheses about why invasive species are successful. Some hypothesized mechanisms are reproductive ability, vegetative growth, predation, adaptation, and allelopathy [18] These competitive mechanisms can provide substantial socio-economic, landscape, and ecological services, both in native and non-native species [23].

Generally, ecosystem services are defined as the output of natural systems from which humans can derive benefits. They have been categorized into four categories by the 
Millennium Ecosystem Assessment [24]: cultural, provisioning, supporting, and regulating. This assessment has been created to qualitatively test the effects of singular species and give useful inputs for effective environmental management. $D$. viscosa is known to offer a large variety of ecosystem functions in the Mediterranean basin. It is an important species that can be used for phytoremediation, as a bio accumulator or bioindicator, as well as an additional tool in ecological agriculture [25-27]. For example, D. viscosa is a host plant for natural enemies (the parasitic complex of Myopites stylata and Eupelmus urozonus) of plant pests like olive fruit fly (Bactrocera oleae Gmel.) [28].

Provisioning of potentially useful compounds to humans is an important ecosystem service. Plant species can be a consolidated source of bioactive components, and many higher plants possess allopathic potential $[29,30]$, which can be investigated and used for the development of commercial natural herbicides. Plant-derived natural products have also served as an important resource for medicinal compounds. D. viscosa contains several biologically active compounds: flavonoids, sesquiterpene lactones, sesquiterpene acids, and triterpenes [31].

The aims of this review are to: (i) review and summarize the current state of knowledge regarding $D$. viscosa invasiveness potential; (ii) provide an overview of $D$. viscosa ecosystem services; (iii) provide information for the effective management of the species in changing habitats and asses its contribution to the ecosystem.

\section{Dittrichia viscosa Invasive Properties}

It is difficult to identify factors associated with the degree of invasion by alien plants. It is certain that invasive species are more plastic in a variety of traits. Still, it remains extremely difficult to define a set of traits responsible for particular species invasiveness [32]. D. viscosa has the potential to be a serious environmental weed both in native and introduced areas.

\subsection{D. viscosa in Native Areas}

It shows a great pioneer character and, in recent years, has largely expanded its range in many Mediterranean countries, possibly due to increased human disturbances [33]. According to Wacquant [34] the species areal has been expanding in the Mediterranean for the previous 25 years. He described the capability of D. viscosa to colonize new habitats and threaten biodiversity, mostly due to its phenotypic plasticity [35]. It has been proven that climatic changes can drive the spread of thermophilic species, such as D. viscosa. Vesperinas et al. [12] correlated the expansion of these species with mean temperature increases.

According to different authors $D$. viscosa has a number of characteristics that makes it highly competitive in its native range:

\subsubsection{Biology}

Morphological and anatomical characteristics that make D. viscosa a good invader are: substantial roots even in small plants, dense canopy, presence of glandular hairs on leaves and stems, strong odor, the glandular hairs secrete lipids, polysaccharides, and proteins.

\subsubsection{Reproduction, Regeneration, and Dispersal}

$D$. viscosa is a prolific seed producer, but the longevity and viability of $D$. viscosa seeds are unknown [36]. D. viscosa tolerates salty soil with small amounts of available water and germination is favored by ground disturbance and fire. It can withstand soils with salinity of sea water level, approx. $30 \mathrm{~g} \mathrm{NaCl} / \mathrm{L}$ [37]. Dittrichia viscosa can be regenerated in several ways. One is by seeds which can be collected at the end of October, the second is through cuttings, and the third is the transplantation of whole plants. Although in nature germinates the following year without interventions, the germination rates in the pots are poor [36]. The impact of salinity on the germination rate of D. viscosa in Slovenia was studied by Grašič et al. [38]. The authors concluded that even though D. viscosa seed is 
highly resistant to salinity, elevated salinity levels cannot be considered the main factor in determining its occurrence.

\subsubsection{Allelopathy}

D. viscosa is rich in secondary compounds such as flavonoids, sesquiterpenes and essential oils [36]. The allelopathic potential of the leaf exudates increases during the dry, hot, and sunny summer. Seasonal and geographic variations have also been found, but all inside native growing areas [39]. Dor and Hershenhorn [40] also revealed that D. viscosa produces sesquiterpene lactone, tayunin, which inhibits the growth of other nearby plants. Moreover, D. viscosa extracts can delay germination of other plants by reducing the frequency of dividing cells in the root $[4,41]$.

\subsubsection{Tolerance of a Broad Range of Environmental Conditions}

Different authors $[8,33,42]$ have described its high tolerance to salinity and unfavorable conditions. Al Hassan et al. [33] have evaluated the potential risk that $D$. viscosa represents for Mediterranean salt marsh vegetation, and it depended on its salt tolerance. They proved that $D$. viscosa prefers anthropically influenced or degraded communities and that the lower salinity makes it more competitive. D. viscosa can compromise some less tolerant species and general biodiversity. They also explain mechanisms responsible for stress tolerance in this species. D. viscosa is a ruderal plant, grows in abandoned fields, roadsides, walking trails, urban areas, and all modified and altered areas by anthropic activities $[36,43,44]$.

\subsubsection{Lack of Predators}

\subsection{D. viscosa in New Areas}

De Laurentis et al. [39] recorded that the chemical composition and concentration of volatile constituents of $D$. viscosa from different areas in Italy were different. This indicates the possibility that, also in the introduced areas, the chemical composition could be different. Still, site-specific studies are needed to prove this assumption.

In the USA, California pest rating was performed according to plant's invasive characteristics and observed behavior on the site [45]. D. viscosa was rated as a species with high risk (score 3/3) to establish a widespread distribution, high risk for a host range, high risk for reproduction and dispersal, medium economic impact, and high environmental impact.

In Australia, where D. viscosa is considered a serious environmental weed marked for eradication flowering occurs between December and April. As in native areas, D. viscosa spreads by seed. Seed can also be spread during construction works or when attached to machinery. Germination is generally enhanced by fire or mechanical disturbance which creates bare ground. Under laboratory conditions, D. viscosa seeds undergo a deep dormancy, which is broken by a lack of light [46]. Generally, it is indicated as a drought-resistant and salt tolerant species $[37,47]$, but it is occasionally found in Australia in swamps and along waterways [45]. There are no specific investigations on the invasive properties of $D$. viscosa in introduced areas and available information on which characteristics are climate or site-specific.

\section{Dittrichia viscosa Ecosystem Services}

Ecosystem services are the outputs of natural systems from which humans derive benefits [23]. Invasiveness can induce losses in ecosystem services. However, novel services are resulting from the characteristics of invasive species as well. The review of $D$. viscosa ecosystem services shows that it successfully meets many contemporary environmental and social needs. In its native range, D. viscosa provides several ecosystem services and functions, presented in Table 1.

These useful services have been arranged and grouped within the Millennium Ecosystem Assessment [24]. In the Table, all ecosystem services provided by D. viscosa have been investigated and summarized within four main groups. In general, provisional ecosystem services include food, fiber, genetic resources, pharmaceuticals and fresh water. Within this 
group, $D$. viscosa provides several services. The most studied services of $D$. viscosa (Table 1 ) are medicinal services and weed and pest control. For example, leaf extracts of $D$. viscosa contain antifungal agents which inhibit the growth of dermatophytes and Candida albicans, a group of fungi that cause a skin disease in animals and humans [31]. Additionally, both leaf extracts and dry leaves proved to be effective herbicides for use in organic agriculture. The extracts decreased seed germination of several weed species: Sinapis arvensis L., Amaranthus palmeri S. Wats., and Solanum nigrum L. [40]. Leaf extracts can also be used for the preparation of natural nematicides. The root-knot nematode Meloidogyne javanica causes severe damage in vegetable crops in Israel, especially in organic vegetable production systems. The use of D. viscosa extracts reduced nematode infection on tomato plants [58]. Regulating ecosystem services such as pollination, climate regulation, air quality regulation, and supporting services are important but global and not specific to D. viscosa. Cultural ecosystem services are expressed through aesthetic value, ecotourism, preservation of traditional practices. $D$ viscosa is a plant known in Mediterranean traditional medicine and agricultural practices (Table 1).

Table 1. Ecosystem services, as defined by the Millennium Ecosystem Assessment [24], provided by Dittrichia viscosa.

\begin{tabular}{ccc}
\hline Category & $\begin{array}{c}\text { Example of Service Provided } \\
\text { by } \boldsymbol{D} \text {. viscosa }\end{array}$ & References \\
\hline Provisioning & Medicinal & {$[31,48-53]$} \\
\hline & Weed management & {$[4,8,54,55]$} \\
\hline & Pest control & {$[40,56-60]$} \\
\hline Regulating & Antifungal control & {$[31,61-64]$} \\
\hline & Biomass production & {$[65]$} \\
\hline & Bioindicator & {$[36,66,67]$} \\
\hline Cultural & Bioaccumulator & {$[36,68-71]$} \\
\hline & Phytoremediation & {$[36,43,55,72,73]$} \\
\hline Supporting & Desertification control & {$[33,42,74]$} \\
\hline & Traditional use & {$[34]$} \\
\hline & Biogeographical component & {$[51,75,76]$} \\
\hline & Primary production & {$[77,78]$} \\
\hline & Nutrient cycling & {$[41,79]$} \\
\hline & Soil formation & {$[80]$} \\
\hline
\end{tabular}

Invasive plant species represent a natural resource that can be freely collected without anthropogenic pressure on local resources in their natural habitats. The use of this resource can be a control method of invasive species and contributes to the ecological balance. Moreover, the collection of these species can produce economic and social benefits, especially in rural areas. Additional potential remains for D. viscosa in provisioning of useful phytochemicals. Certainly, in order to realize this potential, site-specific researches are needed.

\section{Plant Chemistry as a Competitive Advantage and Potential Ecosystem Service}

It is often assumed that alien plants can become invasive when they possess novel secondary metabolites compared to the native plants in the introduced range. High chemical diversity and phytochemical uniqueness in alien species could indicate biological invasion potential [30]. Moreover, data on chemical properties can provide a background for possible approaches to restrict and control invasive populations and are of considerable taxonomic interest. A study by Brahmi-Chendouh et al. [81] revealed the chemical com- 
position of $D$. viscosa extracts, highlighting its diversity in polyphenolic constituents and the abundance of bioactive nutraceutical phytochemicals. Trimech et al. [82] described the metabolic profile of $D$. viscosa and the structures of the major polyphenolic constituents tentatively assigned based on their MS and UV-VIS spectra. Caffeic acid, also present in $D$. viscosa derivatives, plays an important role in the plants' defence against pathogens and insects $[83,84]$. They also participate in processes that promote herbicidal properties [85].

The search for new natural phytotoxins that can be applied in agriculture as target herbicides recently increased [86]. The allelopathic potential of $D$. viscosa can be found in its leaf leachate, which could be used in irrigation for sustainable weed management [55]. The high diversity of bioactive compounds in $D$. viscosa extracts highlights its significant potential for use in agriculture and pharmaceutics.

\section{Invasive Native-Non Native $D$. viscosa}

Despite the broad scientific interest on the topic, the "invasive-native-non-native" terminology is still unresolved [33]. Some scientists identify native species with invasive characteristics as "expansive" or "super-dominant" [87]. Others distinguish invasive species from transformers, not harmful species, and weeds, which can be non-native species, but not necessarily [88]. In our case, D. viscosa is classified as a weed, a native species that often grows in the Mediterranean area in sites where it is not wanted and has detectable economic or environmental impacts [89]. It is also classified as a non-native invasive outside its range of origin. Invasiveness is a dynamic process influenced by changing environmental parameters $[15,90]$. Many studies relate invasiveness to biotic and abiotic conditions, but the underlying mechanisms are still unclear, i.e., which variables best correlate to the observed patterns of richness and abundance [91]. Human activities such as pollution and land-use change often result in rapid environmental shifts [92,93]. Moreover, climate change is considered one of the major causes of disturbances to ecological conditions and poses an additional challenge to our ability to manage invasiveness. Due to their adaptability to climate change disturbance, such as increased temperatures and $\mathrm{CO}_{2}$ concentrations, invasive species have increased opportunities for a spread in a broad range of geographic conditions [94]. Under changing local conditions, any species, regardless of origin (native or non-native), can respond with novel ecological behaviors and assume invasive characteristics. There are several examples where native species are considered invasive; for instance, the fern Pteridium aquilinum (L.) Kuhn. and the shrub Ulex europaeus L. [95].

In this review, we are discussing an example of an expressed change in the species distribution pattern, noticed on a local scale in Croatia. Local changes provoked native D. viscosa behavior change, expressing its competitive characteristics and becoming an abundant weed in Croatian coastal areas (Figure 1). As in many places in the Mediterranean, complex socio-economic and environmental factors resulted in such changes. Rural depopulation and land abandonment are common in Croatia, but little is known about their impact on biodiversity and population dynamics. Although there are numerous case studies on the impacts of land abandonment in the Mediterranean basin [96], there are limited studies on these processes in Croatia [97]. Among the most significant processes of global environmental change [98], the termination of crop cultivation and livestock grazing, seen in rural areas, could be some of the main reasons behind recent increases in abundance of $D$. viscosa and other similar weeds in coastal Croatia. The invasive properties overviewed in this study are the background of evidence for spreading, which will develop under specific conditions. However, the data on its invasion dynamics remains scarce [36].

When given the opportunity, native species can move into new areas where they have a competitive advantage over indigenous ones [99]. They can exhibit aggressive characteristics — such as demographic explosions, biomass accumulation, high reproductive output, phenotypic plasticity, and novel reproductive strategies-becoming weeds [100,101]. Some weeds are particularly concerning and have been listed as a priority for agricultural management or legislation. D. viscosa is listed in the Alert List of Environmental Weeds of 
Australia [2]. The list comprises 28 non-native plants that threaten biodiversity and cause other environmental and economic damage. These weeds have the potential to degrade Australia's ecosystems seriously. It is not clear how D. viscosa was introduced to Australia, but it may have been introduced by horticulturalists. Throughout Australia, weeds are spreading uncontrollably fast, and their management is consuming an enormous amount of resources. Particularly, considering their potential for negative effect, such as reducing agricultural production, damaging infrastructure, and can negatively influence human health or well-being [102].

\section{Species Management}

When $D$. viscosa is treated as weed it needs proper management measures, but it can also be used as a management mean for other weed removals. Effective management strategies require detailed assessments of both the positive aspects of species in an ecosystem and the negative impacts of their invasiveness [103]. The goal is to manage invasive species in a way that establishes balanced and controlled ecosystems, providing a high level of possible ecosystem services. This is especially valid for native habitats in which there are natural mechanisms of species control. In new habitats, though, these species deserve special attention in recognition of their costs and management models. In the case study of buffelgrass in Australia, Grice and the authors created broadscale strategic solutions for the management of this species. Many invasive species, D. viscosa including, are contentious species and management approaches could follow the same direction as Grice et al. [104] proposed. The results and observations presented in this review highlight the fragility of environmental balance, as well as the unexplored potential of $D$. viscosa. Systematic research on the invasion dynamics and ecosystem services provisioning of D. viscosa, as well as complex large scale strategies and actions, are needed to establish sustainable management plans.

Different authors $[40,105]$ have proved that $D$. viscosa chemical properties can be useful in weed germination inhibition, and therefore used as a biological herbicide. They identified that allelopathic activity changed during the vegetation; extracts from leaves collected in spring were more active than those collected in autumn. D. viscosa could also be used as a secondary plant in biological control [1]. Moreover, this species has shown a significant potential in soil management, in particular in use for phytoremediation in mining-affected semiarid soils, since it is an efficient bioaccumulator of trace metals [33].

\section{Conclusions}

Motivated by observed changes in Dittrichia viscosa behavior, with a particularly noticeable negative impact on agriculture, in this review, we add and summarize valuable information to the existing knowledge on this species. Ecosystem disturbances and constant changes in environmental conditions can easily compromise the ecological balance. Climate change poses risks that vary greatly geographically. Phytochemicals present in the plant organs of $D$. viscosa make it a promising resource for use in organic agriculture and phytomedicine. The positive aspects of species in any ecosystem have to be weighed against the loss of other ecosystem services. Habitat-specific studies are essential to adopt goal-specific measures in the management of D. viscosa. Still, it is more likely to use the plant in the native environment as an ecosystem provider and try to control its spread and eradicate when possible in the new habitats. Additional studies on the possible uses of extracts from $D$. viscosa for the purpose of controlling weeds in agriculture and other uses of this species in soil management would also be beneficial.

Author Contributions: All authors have contributed significantly to the present work. In particular, B.S. and D.P. to conceptualization; B.S., D.P., M.U. and M.M.-P. to methodology development, analysis performance, and investigation; M.K. and M.U. to field sampling and data curation; M.U. to original draft preparation, and M.K. to vizualisation. All authors have contributed to writing, editing and proof checking. B.S. and M.M.-P. moreover to project administration and funding acquisition. All authors have read and agreed to the published version of the manuscript. 
Funding: This work was supported by the Croatian-Slovenian bilateral project funded by the Croatian Ministry of Science and Technology and Horticulture program no. P4-0013-0481 funded by the Slovenian Research Agency (ARRS).

Acknowledgments: We especially thank Slavko Brana and Istrian Botanical Society for help in the fieldwork and availability.

Conflicts of Interest: The authors declare no conflict of interest. The funders had no role in the design of the study; in the collection, analyses, or interpretation of data; in the writing of the manuscript, or in the decision to publish the results.

\section{References}

1. Parolin, P.; Scotta, I.; Bresch, C. Biology of Dittrichia viscosa, a Mediterranean ruderal plant: A review. Phyton 2014, 83, 251-262.

2. Ounoughi, A.; Ramdani, M.; Lograda, T.; Chalard, P.; Figuérédo, G. Chemotypes and antibacterial activities of Inula viscosa essential oils from Algeria. Biodiversitas J. Biol. Divers. 2020, 21, 1504-1517. [CrossRef]

3. Glanznig, A.; Kessal, O. Invasive Plants of National Importance and Their Legal Status by State and Territory; WWF-Australia: Sydney, Australia, 2004; pp. 19-21.

4. Araniti, F.; Lupini, A.; Sunseri, F.; Abenavoli, M.R. Allelopatic Potential of Dittrichia viscosa (L.) W. Greuter Mediated by VOCs: A Physiological and Metabolomic Approach. PLoS ONE 2017, 12, e0170161. [CrossRef]

5. Šugar, I. Vegetacijska Karta SR Hrvatske List 77; Botanički zavod PMF: Pula, Hrvatska, 1978.

6. GBIF Secretariat. GBIF Backbone Taxonomy. 2021. Checklist Dataset. Available online: https://www.gbif.org/species/3101184 (accessed on 2 August 2021).

7. Di Pietro, R.; Germani, D.; Fortini, P. A phytosociological investigation on the mixed hemycryptophitic and therophitic grasslands of the Cornicolani mountains (Lazio Region-central Italy). Plant Sociol. 2017, 54, 107-128. [CrossRef]

8. Hulme, P. Weed risk assessment: A way forward or a waste of time? J. Appl. Ecol. 2011, 49, 10-19. [CrossRef]

9. Grašič, M.; Anžlovar, S.; Strgulc Krajšek, S. Germination rate of stinkwort (Dittrichia graveolens (L.) Greuter) and false yellowhead (D. viscosa (L.) Greuter) in relation to salinity and the impact of their extracts on germination of selected plant species. In Proceedings of the 6th Slovenian Symposium on Plant Biology, Hoče, Maribor, Slovenia, 12 September 2014.

10. Cramer, V.; Hobbs, J.R.; Standish, R. What's new about old fields? Land abandonment and ecosystem assembly. Ecol. Evol. 2008, 23, 104-112. [CrossRef]

11. Seabloom, E.; Williams, J.; Slayback, D.; Stoms, D.; Viers, H.J.; Dobson, A.P. Human impacts, plant invasion, and imperiled plant species in California. Ecol. Appl. 2006, 16, 1338-1350. [CrossRef]

12. Brook, B.; Sodhi, S.N.; Bradshaw, C. Synergies among extinction drivers under global change. Ecol. Evol. 2008, 23, 453-460. [CrossRef]

13. Vesperinas, E.S.; Moreno, A.G.; Elorza, M.S.; Sánchez, E.D.; Mata, D.S.; Gavilán, R. The Expansion of Thermophilic Plants in the Iberian Peninsula as a Sign of Climatic Change. In "Fingerprints" of Climate Change; Walther, G.R., Burga, C.A., Edwards, P.J., Eds.; Springer: Boston, MA, USA, 2001; pp. 163-184.

14. Doroftei, M.; Anastasiu, P. Potential Impacts of Climate Change on Habitats and Their Effects on Invasive Plant Species in Danube Delta Biosphere Reserve, Romania. In Managing Protected Areas in Central and Eastern Europe Under Climate Change: Advances in Global Change Research; Rannow, S., Neubert, M., Eds.; Springer: Dordrecht, The Netherlands, 2014; pp. 267-278.

15. Hoveka, L.N.; Bezeng, B.S.; Yessoufou, K.; Boatwrigh, J.S.; Van der Bank, M. Effects of climate change on the future distributions of the top five freshwater invasive plants in South Africa. S. Afr. J. 2016, 102, 33-38. [CrossRef]

16. Hellmann, J.J.; Byers, J.E.; Bierwagen, B.G.; Dukes, J.S. Five potential consequences of climate change for invasive species. Biol. Conserv. 2008, 22, 534-543. [CrossRef] [PubMed]

17. Cronk, Q.C.B.; Fuller, J. Plant Invaders: The Threat to Natural Ecosystems. In Plant Invaders; Cronk, Q.C.B., Ed.; Earthscan Publications: London, UK, 1995.

18. Kolar, C.S.; Lodge, D.M. Progress in invasion biology: Predicting invaders. Ecol. Evol. 2001, 16, 199-204. [CrossRef]

19. Arim, M.; Abades, S.; Neill, P.; Lima, M.; Marquet, P. Spread dynamics of invasive species. Proc. Natl. Acad. Sci. USA 2006, 103, 374-378. [CrossRef] [PubMed]

20. Sebert-Cuvillier, E.; Paccaut, F.; Chabrerie, O.; Endels, P.; Goubet, O.; Decocq, G. Local population dynamics of an invasive tree species with a complex life-history cycle: A stochastic matrix model. Ecol. Model. 2007, 201, 127-143. [CrossRef]

21. Lind, E.M.; Parker, J.D. Novel Weapons Testing: Are Invasive Plants More Chemically Defended than Native Plants? PLoS ONE 2010, 5. [CrossRef]

22. Bennett, A.E.; Thomsen, M.; Strauss, S.Y. Multiple mechanisms enable invasive species to suppress native species. Am. J. Bot. 2011, 98, 1086-1094. [CrossRef] [PubMed]

23. Dormontt, E.E.; Lowe, A.J.; Prentis, P.J. Is rapid adaptive evolution important in successful invasions? In Fifty Years of Invasion Ecology The Legacy of Charles Elton; Richardson, D.M., Ed.; Wiley-Blackwell: Shichester, UK, 2011; pp. 175-193.

24. Sladonja, B.; Sušek, M.; Guillermic, J. Review on invasive tree of heaven (Ailanthus altissima (Mill.) Swingle) conflicting values: Assessment of its ecosystem services and potential biological threat. J. Environ. Manag. 2015, 56, 1009-1034. [CrossRef] 
25. Millennium Ecosystem Assessment, Ecosystems and Human Well-being: Synthesis. Available online: https://www. millenniumassessment.org/documents/document.356.aspx.pdf (accessed on 13 October 2020).

26. Kavallieratos, N.G.; Stathas, G.J.; Athanassiou, C.G.; Tomanović, Ž. Aphid parasitoids (Hymenoptera: Braconidae: Aphidiinae) on citrus: Seasonal abundance, association with the species of host plant, and sampling indices. Phytoparasitica 2002, 30, 231. [CrossRef]

27. Cohen, Y.; Wang, W.; Ben-Daniel, B.H.; Ben-Daniel, Y. Extracts of Inula viscosa control downy mildew of grapes caused by Plasmopara viticola. Phytopathology 2006, 96, 417-424. [CrossRef]

28. Jaber, L.R.; Araj, S.E.; Qasem, J.R. Compatibility of endophytic fungal entomopathogens with plant extracts for the management of sweetpotato whitefly Bemesia tabaci Gennadius (Homoptera: Aleyrodidae). Biol. Control. 2018, 117, 164-171. [CrossRef]

29. Cobo, A.; González-Núñez, M.; Sánchez-Ramos, I.; Pascual, S. Selection of non-target tephritids for risk evaluation in classical biocontrol programmes against the olive fruit fly. J. Appl. Entomol. 2015, 139, 179-191. [CrossRef]

30. Kožuharova, E.; Lebanova, H.; Getov, I.; Benbassat, N.; Kochmarov, V. Ailanthus altissima (Mill.) Swingle-a terrible invasive pest in Bulgaria or potential useful medicinal plant? Bothalia J. 2014, 44, 213-229.

31. Macel, M.; de Vos, R.C.H.; Jansen, J.J.; van der Putten, W.H.; van Dam, N.M. Novel chemistry of invasive plants: Exotic species have more unique metabolomic profiles than native congeners. Ecol. Evol. 2014, 4, 2777-2786. [CrossRef] [PubMed]

32. Maoz, M.; Neeman, I. Effect of Inula viscosa extract on chitin synthesis in dermatophytes and Candida albicans. J. Ethnopharmacol. 2000, 71, 479-482. [CrossRef]

33. Bresch, C.; Mailleret, L.; Muller, M.M.; Poncet, C.; Parolin, P. Invasive plants in the Mediterranean basin: Which traits do they share? J. Mediterr. Ecol. 2013, 12, 13-19.

34. Al Hassan, M.; Chaura, J.; López-Gresa Pilar, M.; Borsai, O.; Daniso, E.; Donat, P.; Mayoral, O.; Vicente, O.; Boscaiu, M. NativeInvasive Plants vs. Halophytes in Mediterranean Salt Marshes: Stress Tolerance Mechanisms in Two Related Species. Front. Plant Sci. 2016, 7, 1438. [CrossRef] [PubMed]

35. Wacquant, P.J. Biogeographical and physiological aspects of the invasion by Dittrichia (ex-Inula) viscosa. In A Ruderal Species in the Mediterranean Basin; Greuter, W., Ed.; Kluwer: Dordrecht, The Netherlands, 1990; pp. 353-364.

36. Wacquant, J.P.; Bouab, N. Nutritional differentiation within the species Dittrichia viscosa W. Greuter, between a population from a calcareous habitat and another from an acidic habitat. In Genetic Aspects of Plant Nutrition, Developments in Plant and Soil Sciences; Sarić, M.R., Loughman, B.C., Eds.; Springer: Dordrecht, The Netherlands, 1983; pp. 285-291.

37. Parolin, P.; Scotta, I.M.; Bresch, C. Notes on the phenology of Dittrichia viscosa. J. Mediterr. Ecol. 2013, 12, 27-35.

38. Aronson, J.A. HALOPH: A Data Base of Salt Tolerant Plants of the World; Office of Arid Land Studies, University of Arizona: Tucson, AZ, USA, 1989.

39. Grašič, M.; Anžlovar, S.; Strgulc Krajšek, S. Germination rate of stinkwort (Dittrichia graveolens) and false yel-lowhead (D. viscosa) in relation to salinity. Acta. Biol. Slov. 2016, 59, 5-11.

40. De Laurentis, N.; Losacco, V.; Milillo, M.A.; Lai, O. Chemical investigations of volatile constituents of Inula viscosa (L.) Aiton (Asteraceae) from different areas of Apulia, Southern Italy. Delpinoa 2002, 44, 115-119.

41. Dor, E.; Hershenhorn, J. Allelopathic effects of Inula viscosa leaf extracts on weeds. Allelopathy. J. 2012, 30, $281-290$.

42. Levizou, E.; Karageorgou, P.G.K.; Manetas, Y. Inhibitory effects of water soluble leaf leachates from Dittrichia viscosa on lettuce root growth, statocyte development and graviperception. Flora-Morphol. Distrib. Funct. Ecol. Plants 2002, 197, 152-157. [CrossRef]

43. Curadi, M.; Graifenberg, A.; Magnani, G.; Giustiniani, L. Growth and element allocation in tissues of Inula viscosa in sodic-saline conditions: A candidate for programs of desertification control. Arid. Land Res. Manag. 2005, 19, 257-265. [CrossRef]

44. Murciego, A.M.; Sanchez, A.G.; Gonzalez, M.R.; Gil, E.P.; Gordillo, C.T.; Fernandez, J.C.; Triguero, T.B. Antimony distribution and mobility in topsoils and plants (Cytisus striatus, Cistus ladanifer and Dittrichia viscosa) from polluted Sb-mining areas in Extremadura (Spain). Environ. Pollut. 2007, 145, 15-21. [CrossRef]

45. Perdikis, D.; Favas, C.; Lykouressis, D.; Fantinou, A. Ecological relationships between non-cultivated plants and insect predators in agroecosystems: The case of Dittrichia viscosa (Asteraceae) and Macrolophus melanotoma (Hemiptera: Miridae). Acta Oecol. 2007, 31, 299-306. [CrossRef]

46. Pest Rating Proposals and Final Rating for Dittrichia viscosa. Available online: https://blogs.cdfa.ca.gov/Section3162/?tag= dittrichia-viscosa (accessed on 28 May 2020).

47. Weeds Australia. Centre for Invasive Species Solutions, Canberra. Available online: https://profiles.ala.org.au/opus/weedsaustralia/profile/Dittrichia\%20viscosa (accessed on 18 June 2021).

48. Zurayk, R.; Khoury, N.; Talhouk, S.; Baalbaki, R. Salinity-Heavy Metal Interactions in Four Salt-tolerant Plant Species. J. Plant Nutr. 2001, 24, 1773-1786. [CrossRef]

49. Cafarchia, C.; De Laurentis, N.; Milillo, M.A.; Losacco, V.; Puccini, V. Fungistatic activity of a sesquiterpene lactone (tomentosin) isolated from fresh Inula viscosa (Asteraceae) flowers from the Puglia region. Parasitologia 2001, 43, 117-121.

50. Passalacqua, N.G.; Guarrera, P.M.; De Fine, G. Contribution to the knowledge of the folk plant medicine in Calabria region (Southern Italy). Fitoterapia 2007, 78, 52-68. [CrossRef]

51. Musthaba, S.M.; Athar, M.T.; Kamal, Y.T.; Baboota, S.; Javed, A.; Sayeed, A. Fast analysis and validation of rutin in anti-psoriatic ayurvedic formulation by HPLC. J. Liq. Chromatogr. Relat. Technol. 2011, 34, 446-455. [CrossRef]

52. Seca, A.; Grigore, A.; Pinto, D.; Silva, A. The genus Inula and their metabolites: From ethnopharmacological to medicinal uses. J. Ethnopharmacol. 2014, 154, 286-310. [CrossRef] 
53. Merghoub, N.; El Btaouri, H.; Benbacer, L.; Gmouh, S.; Trentesaux, C.; Brassart, B.; Terryn, C.; Attaleb, M.; Madoulet, C.; Benjouad, A.; et al. Inula Viscosa Extracts Induces Telomere Shortening and Apoptosis in Cancer Cells and Overcome Drug Resistance. Nutr. Cancer 2016, 68, 131-143. [CrossRef] [PubMed]

54. Lounis, H.; Bergheim, I.; Bouhaimi, A.; Guigonis, J.M.; Belhamel, K. Anti-inflammatory and antioxidant activities of Inula viscosa and Senecio anteuphorbium. Orient. Pharm. Exp. Med. 2018, 18, 225-236. [CrossRef]

55. Askin, C.T.; Aslantürk, T.S. Evaluation of Cytotoxicity and Genotoxicity of Inula viscosa Leaf Extracts with Allium Test. J. Biomed. Biotechnol. 2010, 8. [CrossRef]

56. Omezzine, F.; Rinez, A.; Ladhari, A.; Farooq, M.; Haouala, R. Allelopathic potential of Inula viscosa against crops and weeds. Int. J. Agric. Biol. 2011, 13, 841-849.

57. Oka, Y.; Ben-Daniel, B.H.; Cohen, Y. Nematicidal activity of powder and extracts of Inula viscosa. J. Nematol. 2001, 3, 735-742.

58. Mansour, F.; Azaizeh, H.; Saad, B.; Tadmor, Y.; Abo-Moch, F.; Said, O. The potential of middle eastern flora as a source of new safe bio-acaricides to control Tetranychus cinnabarinus, the carmine spider mite. Phytoparasitica 2004, 32, 66-72. [CrossRef]

59. Oka, Y.; Ben-Daniel, B.H.; Cohen, Y. Control of Meloidogyne javanica by formulations of Inula viscosa leaf extracts. J. Nematol. 2006, 38, 46. [CrossRef]

60. Alexenizer, M.; Dorn, A. Screening of medicinal and ornamental plants for insecticidal and growth regulating activity. J. Pest Sci. 2007, 80, 205-215. [CrossRef]

61. Sofou, K.; Isaakidis, D.; Spyros, A.; Büttner, A.; Giannis, A.; Katerinopoulos, H. Use of costic acid, a natural extract from Dittrichia viscosa, for the control of Varroa destructor, a parasite of the European honey bee. Beilstein J. Org. Chem. 2017, 13, 952-959. [CrossRef]

62. Cohen, Y.; Baider, A.; Ben-Daniel, B.; Ben-Daniel, Y. Fungicidal preparations from Inula viscosa. Plant Prot. Sci. 2002, 38, 629-630. [CrossRef]

63. Wang, W.; Ben-Daniel, B.; Cohen, Y. Control of Plant Diseases by Extracts of Inula viscosa. Phytopathology 2004, 94, 1042-1047. [CrossRef] [PubMed]

64. Talib, W.; Abu Zarga, M.; Mahasneh, A. Antiproliferative, Antimicrobial and Apoptosis Inducing Effects of Compounds Isolated from Inula viscosa. Molecules 2012, 17, 3291-3303. [CrossRef]

65. Al-Masri, M.I.; Sharawi, S.M.; Barakat, R.M. Effect of Clammy Inula (Inula viscose) Plant Extract in Combination with a Low Dose of the Fungicide Iprodione on Botrytis cinerea In Vitro and In Vivo. Am. J. Plant Sci. 2015, 6, 1519-1526. [CrossRef]

66. Dominguez, M.; Madejón, P.; Madejón, E.; Díaz Blanco, M. Novel energy crops for Mediterranean contaminated lands: Valorization of Dittrichia viscosa and Silybum marianum biomass by pyrolysis. Chemosphere 2017, 186, 976-986. [CrossRef] [PubMed]

67. Ater, M.; Lefèbvre, C.; Gruber, W.; Meerts, P. A phytogeochemical survey of the flora of ultramafic and adjacent normal soils in North Morocco. Plant Soil 2000, 218, 127-135. [CrossRef]

68. Swaileh, K.; Hussein, R.; Abu-Elhaj, S. Assessment of Heavy Metal Contamination in Roadside Surface Soil and Vegetation from the West Bank. Arch. Environ. Contam. Toxicol. 2004, 23, 22-30. [CrossRef]

69. Gisbert, C.; Almela, C.; Vélez, D.; López-Moya, J.R.; Serrano, R.; Montoro, R.; Navarro-Aviñó, J. Identification of As accumulation plant species growing on highly contaminated soils. Int. J. Phytoremediation 2008, 10, 183-184. [CrossRef]

70. Conesa, H.; María-Cervantes, A.; Alvarez-Rogel, J.; González, M. Influence of soil properties on trace element availability and plant accumulation in a Mediterranean salt marsh polluted by mining wastes: Implications for phytomanagement. Sci. Total Environ. 2011, 409, 4470-4479. [CrossRef]

71. Perez, C.; Martínez-Sánchez, M.; Martínez-López, S.; Bech, J.; Bolan, N. Distribution and bioaccumulation of arsenic and antimony in Dittrichia viscosa growing in mining-affected semiarid soils in southeast Spain. J. Geochem. Explor. 2012, 123, 128-135. [CrossRef]

72. Pistelli, L.; D'Angiolillo, F.; Morelli, E.; Basso, B.; Rosellini, I.; Posarelli, M.; Barbafieri, M. Response of spontaneous plants from an ex-mining site of Elba island (Tuscany, Italy) to metal (loid) contamination. Environ. Sci. Pollut. Res. Int. 2017, 24, 7809-7820. [CrossRef] [PubMed]

73. Barbafieri, M.; Dadea, C.; Tassi, E.; Bretzel, F.; Fanfani, L. Uptake of heavy metals by native species growing in a mining area in Sardenia, Italy: Discovering native flora for phytoremediation. Int. J. Phytoremediation 2011, 13, 985-997. [CrossRef]

74. Jimenez, M.N.; Bacchetta, G.; Casti, M.; Navarro, F.B.; Lallena, A.M.; Fernández-Ondoñoa, E. Potential use in phytoremediation of three plant species growing on contaminated mine-tailing soils in Sardinia. Ecol. Eng. 2011, 37, 392-398. [CrossRef]

75. Perez-Fernandez, M.A.; Calvo-Magro, E.; Ferrrer-Castan, D. Simulation of germination of pioneer species along an experimental drought gradient. J. Environ. Biol. 2006, 27, 679-685. [PubMed]

76. Gonzalez-Tejero, M.R.; Casares-Porcel, M.; Sánchez-Rojas, C.P.; Ramiro-Gutiérrez, J.M.; Mesa, J.; Pieroni, A.; Giusti, M.E.; Censorii, E.; de Pasquale, C.; Della, A.; et al. Medicinal plants in the Mediterranean area: Synthesis of the results of the project Rubia. J. Ethnopharmacol. 2008, 116, 341-357. [CrossRef] [PubMed]

77. Akkawi, M.; Abbasi, I.; Jaber, S.; Abouremeleh, Q.; Nasereddin, A.; Lutgen, P. Investigation of Traditional Palestinian Medicinal Plant Inula viscosa as Potential Anti-malarial Agent. Br. J. Pharmacol. 2014, 5, 156-162. [CrossRef]

78. Kawada, K.; Vovk, A.G.; Filatova, O.V.; Araki, M.; Nakamura, T.; Hayashi, I. Floristic composition and plant biomass production of steppe communities in the vicinity of Kharkiv, Ukraine. Grassl. Sci. 2005, 51, 205-213. [CrossRef]

79. Zhang, T.; Guo, R.; Gao, S.; Guo, J.; Sun, W. Responses of Plant Community Composition and Biomass Production to Warming and Nitrogen Deposition in a Temperate Meadow Ecosystem. PLoS ONE 2015, 10. [CrossRef] [PubMed] 
80. Karageorgou, P.; Levizou, E.F.I.; Manetas, Y. The influence of drought, shade and availability of mineral nutrients on exudate phenolics of Dittrichia viscosa. Flora 2002, 197, 285-289. [CrossRef]

81. Terradas, J. Mediterranean woody plant growth-forms, biomass and production in the eastern part of the Iberian Peninsula. Oecologia 1990, 10, 337-349.

82. Brahmi-Chendouh, N.; Piccolella, S.; Crescente, G.; Pacifico, F.; Boulekbache-Makhlouf, L.; Hamri-Zeghichi, S.; Akkal, S.; Madani, K.; Pacifico, S. A nutraceutical extract from Inula viscosa leaves: UHPLC-HR-MS/MS based polyphenol profile, and antioxidant and cytotoxic activities. J. Food Drug Anal. 2019, 27, 692-702. [CrossRef] [PubMed]

83. Trimech, I.; Weiss, E.K.; Chedea, V.; Marin, D.; Detsi, A.; Ioannou, E.; Roussis, V.; Kefalas, P. Evaluation of Anti-oxidant and Acetylcholinesterase Activity and Identification of Polyphenolics of the Invasive Weed Dittrichia viscosa. Phytochem. Anal. 2014, 25, 421-428. [CrossRef] [PubMed]

84. Lattanzio, V.; Lattanzino, V.M.T.; Cardinali, A. Role of phenolics in the resistance mechanisms of plants against fungal pathogens and insects. In Phytochemistry. Advances in Research; Imperato, F., Ed.; Research Signpost: Trivandrum, India, 2006 ; pp. $23-67$.

85. Mikulič-Petkovšek, M.; Štampar, F.; Veberić, R. Accumulation of phenolic compounds in apple in response to infection by the scab pathogen, Venturia inaequalis. Physiol. Mol. Plant Pathol. 2009, 74, 60-67. [CrossRef]

86. Orcaray, L.; Igal, M.; Zabalza, A.; Royuela, M. Role of Exogenously Supplied Ferulic and p-Coumaric Acids in Mimicking the Mode of Action of Acetolactate Synthase Inhibiting Herbicides. J. Agric. Food Chem. 2011, 59, 10162-10168. [CrossRef]

87. Dayan, F.E.; Duke, S.O. Natural compounds as next-generation herbicides. J. Plant Physiol. 2014, 166, 1090-1105. [CrossRef]

88. Pyšek, P.; Richardson, D.M. Invasive plants. In Encyclopedia of Ecology; Jørgensen, S.E., Ed.; Elsevier: Amsterdam, The Netherlands, 2008; pp. 2011-2020.

89. Pyšek, P.; Richardson, M.D.; Rejmanek, M.; Webster, G.L.; Williamson, M.; Kirschner, J. Alien plants in checklists and floras: Towards better communication between taxonomists and ecologists. Taxon 2004, 53, 131-143. [CrossRef]

90. James, L.; Evans, J.; Ralphs, M.; Child, R. Noxious Range Weeds; Westview Press: San Francisco, CA, USA, $1991 ;$ pp. $420-428$.

91. Pyšek, P.; Richardson, D.M. Invasive Species, Environmental Change and Management, and Health. Annu. Rev. Environ. Resour. 2010, 35, 25-55. [CrossRef]

92. Niemelä, J. From systematics to conservation-carabidologists do it all. Ann. Zool. Fenn. 1996, 33, 1-4.

93. Jefferies, R. Allochthonous inputs: Integrating population changes and food-web dynamics. Ecol. Evol. 2000, 15, 19-22. [CrossRef]

94. Meiners, S.J. Native and exotic plant species exhibit similar population dynamics during succession. Ecology 2007, 88, 1098-1104. [CrossRef] [PubMed]

95. Burgiel, S.W.; Muir, A.A. Invasive Species, Climate Change and Ecosystem-Based Adaptation: Addressing Multiple Drivers of Global Change; Global Invasive Species Programme (GISP): Washington, DC, USA; Nairobi, Kenya, 2010.

96. Wijesundara, D. Can native plants become invasive? Ceylon J. Sci. 2017, 46, 1-2. [CrossRef]

97. Plieninger, T.; Hui, C.; Gaertner, M.; Huntsinger, L.L. The Impact of Land Abandonment on Species Richness and Abundance in the Mediterranean Basin: A Meta-Analysis. PLoS ONE 2014, 9. [CrossRef] [PubMed]

98. Mikulič, K.; Radović, A.; Kati, V.; Jelaska, S. Effects of land abandonment on bird communities of smallholder farming landscapes in post-war Croatia: Implications for conservation policies. Community Ecol. 2014, 15, 169-179. [CrossRef]

99. Benayas, J.M.R.; Artins, A.; Nicolau, J.M.; Schulz, J.J. Abandonment of agricultural land: An overview of drivers and consequences. CAB. Rev. Perspect. Agric. Vet. Sci. Nutr. Nat. Resour. 2007, 2, 14. [CrossRef]

100. Jackson, W.J.; Argent, R.M.; Bax, N.J.; Bui, E.; Clark, G.F.; Coleman, S.; Cresswell, I.D.; Emmerson, K.M.; Evans, K.; Hibberd, M.F.; et al. Overview: Invasive species are a potent, persistent and widespread threat to Australia's environment. In Australia State of the Environment 2016; Australian Government Department of the Environment and Energy: Canberra, Australia, 2016.

101. Yasumura, Y.; Crumpton-Taylor, M.; Fuentes, S.P.; Harberd, N. Step-by-Step Acquisition of the Gibberellin-DELLA GrowthRegulatory Mechanism during Land-Plant Evolution. Curr. Biol. 2007, 17, 1225-1230. [CrossRef] [PubMed]

102. Ratnayake, R.M.C.S. Why plant species become invasive? Characters Related to Successful Biological Invasion. In Proceedings of the Conference National Symposium on Invasive alien Species, Colombo, Sri Lanka, 11 November 2014.

103. Vilà, M.; Hulme, P. Impact of Biological Invasions on Ecosystem Services; Springer International Publishing: Cham, Switzerland, 2016.

104. Grice, A.C.; Friedel, M.H.; Marshall, N.A.; Van Klinken, R.D. Tackling Contentious Invasive Plant Species: A Case Study of Buffel Grass in Australia. Environ. Manag. 2012, 49, 285-294. [CrossRef]

105. Boari, A.; Vurro, M.; Calabrese, G.; Nesma, M.; Mahmoud, Z.; Cazzato, E.; Fracchiolla, M. Evaluation of Dittrichia viscosa (L.) Greuter Dried Biomass for Weed Management. Plants 2021, 10, 147. [CrossRef] [PubMed] 